\title{
Transfer Pricing Analysis on Intra-Group Services and the Related Transfer Pricing Disputes from Indonesian Tax Perspectives
}

\author{
Beatrice Eka Putri P. Simamora ${ }^{1 *}$, Ancella Anitawati Hermawan ${ }^{1}$ \\ ${ }^{1}$ Faculty of Economics and Business, Universitas Indonesia, Depok 16424, Indonesia \\ *beatricesimamora@gmail.com
}

\begin{abstract}
After analyzing transfer pricing cases on intra-group services transactions in Indonesia which have been settled in the Indonesian Tax Court and/or Supreme Court within the year 2013 to the present day, the result shows that the corrections made by the Directorate General of Tax ("DGT") on intra-group services transactions in Indonesia are mostly because the taxpayer lacked supporting evidences to prove the existence issue, the benefit issue, and the arm's-length charges. Almost half of the Tax Court's decisions were in favor of the taxpayer, with most considering that the supporting evidences provided by the taxpayer before the tax appeal process were already considered sufficient and $80 \%$ of the Supreme Court's decisions upheld the Tax Court's decisions. With regard to the OECD's recently issued transfer pricing guidelines relating to intra-group services, which discuss the simplified approach for compliance to the arm's-length principle of low value-adding services, due to Indonesia's specific economic condition, which is below the economic condition of more developed countries where the related party service provider operates, and the intra-group services are inclined to be seen to have been arranged with transfer pricing motives.
\end{abstract}

Keywords: Transfer Pricing, Arm's Length Principle, Intra-Group Services, Transfer Pricing Dispute.

\section{INTRODUCTION}

With the increased competition in the market, multinational companies are looking for ways to achieve greater efficiency and economies of scale in order to improve their market position. As companies are becoming more international, one of the considered ways is a wide scope of services for group members on a centralized basis (i.e., intra-group services). The growth of multinational companies utilizing intra-group services has triggered extensive scrutiny from the tax authorities. The intra-group services are assumed to be performed with transfer pricing motives to manipulate their profits and as a channel for shifting profits from countries with a higher tax rate to countries with a lower tax rate for the purpose of drastically reducing their tax burden on worldwide income. This has resulted in a significant rise in the type and number of challenges raised by the tax authorities on intra-group service charges in countries around the world ${ }^{1}$.

For multinational companies which operate in Indonesia, the transfer pricing audit environment is becoming tougher, due to the Directorate General of Taxes' ("DGT”) annual increase of the tax revenue target ${ }^{2}$. Consequently, the exposure of the taxpayer having related party transactions to transfer pricing adjustments, specifically on intragroup services, is increasing.

Based on the above concerns, a study is conducted to contribute to the literature on intra-group services related to transfer pricing disputes in Indonesia as well as the latest revision of the Organization for Economic Cooperation and Development (“OECD”) Transfer Pricing Guidelines for Multinational Enterprises and Tax Administrations ("OECD Transfer Pricing Guidelines") ${ }^{3}$ with the focus on (i) the recent trend of transfer pricing disputes related to corrections made by the DGT on intra-group services transactions in Indonesia and the settlement by the Indonesian Tax Court and/or Supreme Court and (ii) the influence of the latest development of international transfer pricing guidelines (specifically as issued by OECD) on intra-group services to the Indonesian transfer pricing climate.

\section{LITERATURE REVIEW}

Transfer pricing rules exist to solve issues such as those discussed above, for example, in determining the proportion of the relevant profits of a certain tax jurisdiction that should be subject to taxation. The globally accepted principle referred to in determining the transfer pricing is the arm's-length principle, which requires related parties, within the context of tax, to distribute income as it would be distributed between independent parties in the similar/same conditions ${ }^{4}$. In Indonesia, the arm's-length principle of transfer pricing is mainly referred to in Article 18 (3) of Law No. 7 of 1983, which was last amended by Law No. 36 of 2008 on Income Tax 
Law (“Income Tax Law”) and Article 2 (1) of Law No. 8 of 1983, which was last amended by Law No. 42 of 2009 on Value-Added Tax on Goods and Services and Sales Tax on Luxury Goods ("VAT Law"). The Indonesian Tax Authority generally endorses the OECD Transfer Pricing Guidelines' principles in its legal products. Nevertheless, it is worth noting that the practical application of the arm's-length principle by the DGT in the context of a tax/transfer pricing audit regularly deviates from the OECD Transfer Pricing Guidelines' principles ${ }^{5}$.

The transfer pricing within the context of those applied in related party transactions is subject to the definition of the Special Relation between Related Parties as referred to by Article 18 (4) of Income Tax Law or Article 2 (2) of the VAT Law. The DGT further has issued the implementing regulations, namely, Regulation of the DGT No. PER-43/PJ/2010 jo. PER-32/PJ/2011 on the Application of Arm's-Length Principle in Transactions between the Taxpayer and the Party Having Special Relations (“PER-43”), which details the step-by-step application of arm'slength principles including the determination of the transfer pricing methodology.

With respect to the multinational companies' transfer pricing practices towards intra-group services transactions, OECD Transfer Pricing Guidelines defines an intra-group service as an activity (e.g., administrative, technical, financial, commercial, etc.) for which an independent enterprise would have been willing to pay or perform for itself $^{4}$. Accordingly, some controversial services may be regarded as non-chargeable services and, as such, need to be addressed separately during the intra-group service evaluation process, such as shareholder activities, duplicative services, services that provide incidental benefits, centralized/shared services, and on-call services. These categories of intra-group services might be deemed to be non-chargeable because the activity performed cannot be categorized as an intra-group service that has been provided. The charge for such services rendered may be built into some other charge and hence cannot be considered under the intra-group service category. Pursuant to Indonesian transfer pricing regulations, specifically in Article 14 paragraph (2) and (3) of PER-43, service transactions are deemed to comply with the arm's-length principle if they satisfy three conditions, namely, the services have actually been rendered, there is benefit derived from the services provided, and the value of the services is the same as the value of the services in an independent transaction. These conditions are already detailed on a step-by-step basis in the DGT's circular letter.

In the case of any transfer pricing controversy, should the case involve an Indonesian taxpayer and the DGT and the taxpayer disagrees with the result of the transfer pricing audit held by the Tax Office (in the form of a Tax Assessment Letter), the taxpayer may seek legal remedies through local dispute resolutions and/or the Mutual Agreement Procedure (“MAP”). Local dispute resolution consists of tax objection (with the DGT (Regional Tax Office) as the authorized body), tax appeal (with the Tax Court as the authorized body), and judicial review (with the Supreme Court as the authorized body). Based on Law No. 6 of 1983 as last amended by Law No. 16 of 2009 on General Taxation Provisions and Procedures ("KUP Law"), each of the aforementioned stages has to be completed before advancing to a higher stage.

\section{RESEARCH METHOD}

The research method used for this study is the qualitative method with the research result in the form of an analytical descriptive study. Regarding the cases, this study refers to the cases uploaded to the Decisions Directory of the Indonesian Supreme Court's website of http://putusan.mahkamahagung.go.id/ and http://www.setpp.depkeu.go.id/. The search for the cases consists of two steps: automatic screening and manual screening. For the automatic screening, this study utilizes Google search engine, which identified 156 cases for further review. For the manual screening, this study selected only cases that were related to the fiscal period/year 2008 onwards, related to transfer pricing disputes (both Value Added Tax (VAT)-related issues and Corporate Income Tax (CIT)-related issues), and/or related to intra-group services disputes, and when either has been decided by the Tax Court only or the Tax Court and Supreme Court. This manual screening identified 39 cases that had been decided by the Tax Court only or the Tax Court and Supreme Court within the period 2013-2015. Based upon the selected cases, analyses are then conducted to assess the taxpayers' historical tax disputes, the characteristics of the disputed intra-group services, the position of the DGT, the taxpayer, the judges of the Tax Court and the judges of the Supreme Court, the trend of the DGT's basis of corrections on intra-group services transactions (pursuant to the steps of the arm's-length principle application on the intra-group's services transactions as required by Director General of Taxes Circular Letter No. SE-50/PJ/2013 on Technical Audit Guidelines For Taxpayer With Special Relationship ("SE-50")), the trend of the Tax Court's considerations and decisions in relation to corrections of intra-group services transactions, and the trend of the Supreme Court's considerations and decisions in relation to the correction of intra-group services transactions.

\section{RESULTS AND DISCUSSION}

To identify the recent trend of transfer pricing disputes related to the correction made by the DGT on intra-group services transactions in Indonesia and the settlement by the Indonesian Tax Court and/or Supreme Court, a comprehensive analysis was conducted on the selected transfer pricing cases. Based on the analysis of the selected 
transfer pricing cases in relation to the dispute settlement in the tax appeal stages and judicial review stage, it can be concluded that $56.41 \%$ of the Tax Court's decisions were in favor of the taxpayer (cancelling the DGT's correction) and the rest were in favor of the DGT; $80 \%$ of the Supreme Court's decisions were in favor of the taxpayer and the rest were in favor of the DGT; $80 \%$ of the Supreme Court's decisions upheld the Tax Court's decision and the rest cancelled the Tax Court's decision.

Based on the analysis of the selected cases, it can be concluded that the taxpayers in transfer pricing disputes related to intra-group services tend to have been exposed to many tax disputes, many of which have been brought to the Tax Court. For the above cases, most of the corrections were related to the corrections on other types of tax. It can also be concluded that an intra-group services transaction tended to be scrutinized if it was a cross-border transaction performed by foreign investment companies. On this, a study on the major determinants of transfer pricing aggressiveness conducted on Australian firms ${ }^{5}$ may have led to this result, as it was found that transfer pricing aggressiveness is significantly and positively related to a company's size, profitability, leverage, intangible assets, and multi nationality. With regard to the taxpayers' relationship with the service providers, the DGT mostly made a correction to intra-group services provided by the (direct/indirect) taxpayers' shareholders. Further, the DGT's corrections tend to not consider whether there are tax motives.

Regarding the dispute on corrections related to intra-group services, the DGT's corrections were mostly because the taxpayer had not provided sufficient supporting evidences. The supporting evidences were expected to show the existence of the services as well as the benefit received. The latter is often difficult to justify, as the benefits are not always received as soon as the service has been provided. As discussed by Siahaan and Riandoko in their paper, an example provided by SE-50 on the benefits received from the services, which is to increase revenues or increase efficiency through the decrease in operating expenses, has been disputed in the Tax Court because the taxpayer disagreed with the opinion that benefits received should be reflected in the financial performance.

To date, there have been no regulations which specifically regulate and/or detail to what extent the documents/information (in terms of amount and detail) should be maintained by the taxpayer to prove the reasonableness of an intra-group services transaction. Nonetheless, for the reviewed cases, the DGT had requested supporting evidences, such as the visas and passports of the service provider's personnel, expertise certification, samples of advice, documentation on actual activities performed as part of the services, and so on.

In most of the cases selected for this study, the DGT concluded that the taxpayers were not able to provide sufficient evidences as requested by the DGT pursuant to Article 28 (3) and Article 29 (3) of KUP Law for the purpose of testing the reasonableness of the intra-group services. This includes the absence of transfer pricing documentation. This study found that none of the above cases disputed the analysis of the arm's-length charges that should be received by the service provider. To date, the search on Indonesian independent comparable third party service providers (e.g., Oriana, Osiris) was difficult due to the limited publicly available data.

Based on the analysis of the selected cases, it can also be concluded that the Tax Court's decisions mostly in favor of the DGT were based on the conclusion that the taxpayer had provided sufficient supporting evidences (both before and during the tax appeal process). In this respect, the DGT would stress that their correction was based on Article 26A (4) of KUP Law whereby data/information which were not provided during the tax audit process could not be considered during the tax objection process and demanded the Tax Court to consider the same. However, the Tax Court relied on the Tax Court Law, specifically, Article 76, which provides that the judges of the Tax Court should uphold the principle of material truth, which includes considering supporting evidences only submitted during the tax appeal process.

With regard to the absence of transfer pricing documentation, some of the judges decided to use a wide interpretation of it by defining transfer pricing documentation as all documents that can be used to describe related party transactions, without being bound to forms and formats, among others; thus, it can be a contract / agreement, proof of payment, and other related documents. PER-43 specifically regulates the format of the transfer pricing documentation for standardization purposes. Further, the judges mostly acknowledged that in the era of information technology, it is possible that the provision of services that require direct engagement with the service providers can be granted without the immediate presence of the party providing the service, and therefore evidences in the form of email correspondences may be considered to show the services were actually rendered and further provided benefit to the service recipient.

Because of the above discrepancy/differences, the treatment/view on supporting evidences may be different between during the tax audit and the tax objection process and during the tax appeal process. This then affects the decision to be made by the judges of the Tax Court. Whilst during the judicial review process, the Supreme Court would assess whether the Tax Court's decision was already in compliance with the prevailing laws and regulations, without any hearings conducted and as such, would consider the tax appeal process, including the facts and evidences discovered and concluded by the Tax Court.

To identify the influence of the latest development of international transfer pricing guidelines (specifically as issued by OECD) on intra-group services towards the Indonesian transfer pricing climate, further analysis was 
conducted on the revisions to Chapter VII of the OECD Transfer Pricing Guidelines (2010 version), which is the result of discussions on the action plan on base erosion and profit shifting ("BEPS") Actions 8-10: Aligning Transfer Pricing Outcomes with Value Creation. The action plan, which is part of the BEPS package for reform of the international tax system to tackle tax avoidance, consists of 13 reports (based upon 15 action plans). The BEPS package is the result of OECD and G20 countries, some of which are major and some developing countries.

Generally, the revisions to Chapter VII of the OECD Transfer Pricing Guidelines ("Revised Chapter VII") introduce a simplified approach for low value-adding services. The definition of low value-adding intra-group services refers to the supportive nature of such services, which are not part of the core business of the multinational company group. The revised Chapter VII proposes an elective, simplified approach which specifies a wide category of common intra-group services which require a very limited profit of mark-up (5\%) on costs, applies a consistent allocation key for all services' recipients, and provides greater transparency through specific reporting requirements including documentation proving the determination of the specific cost pool.

In order for multinational enterprises to apply the simplified guidance, the rules will have to be adopted and applied by the countries in which they provide intra-group services. Questions remain as to how easy it will be for countries to opt out of the rules because threshold levels of charges have been met, or whether countries will fail to adopt the rules because they believe the cost plus margin provided in the rules is inadequate ${ }^{8}$. For Indonesia, the Director of Tax Regulations II $^{2}$ confirmed that an implementation regulation on the revisions to the OECD Transfer Pricing Guidelines as presented in the Report on Actions 8-10: Aligning Transfer Pricing Outcomes with Value Creation is currently drafted. However, as the draft has not yet been published, it is still not clear whether the regulation will fully adopt the guidance on the simplified approach provided by the OECD's revised Chapter VII.

As required and suggested by Indonesian transfer pricing laws and regulations (specifically in Article 18 (3) of Income Tax Law and Article 1(5) of PER-43) and OECD Transfer Pricing Guidelines, pursuant to the arm's-length principle, OECD Transfer Pricing Guidelines highlights the concept of "options realistically available" ${ }^{3}$ which provides that independent companies will compare a potential transaction to the other options realistically available to them and will enter into the transaction only if they have concluded that there is no alternative that would offer a clearly more attractive opportunity to make them meet their commercial objectives.

To this point, the arm's-length nature of an intra-group service provided to Indonesian companies, specifically in the form of day-to-day support services, would be more difficult to defend. In this respect, reasonable independent companies, from a business point of view, would choose to pay a lower price for similar services. As such, should similar services with the intra-group services be also available to be obtained in Indonesia and be offered by an independent service provider, there is a high probability that lower prices will be offered by the Indonesian independent service provider. This is specifically due to the lower price of local labor and operational costs in comparison to the price of labor and operational costs of more developed countries where the related party service provider (e.g., the headquarters or the parent of the taxpayer's group of companies or the designated group member) operates. Furthermore, Indonesia's weak currency can also increase the costs to be recorded by the Indonesian entity which maintains the bookkeeping in Rupiah. The costs then increase the deductible expenses and lower the taxable income. In this case, transfer pricing motives will be mostly indicated, and as such, the issue of the existence of such services which could not be obtained locally or could only be obtained from the related party service provider, and the issue on benefit received should be proven.

As such, the intra-group services are inclined to be seen as having been arranged with transfer pricing motives. Especially for the low-value adding intra-group services, the view on the existence of similar services to be obtained in Indonesia with lower prices becomes arguable and may be reasonable, as the services are supportive in nature and are not creating profit-earning activities, but in fact, are contributing costs. This, definitely, is subject to the supporting evidences provided.

\section{RESULT AND CONCLUSION}

Based on the discussions in the previous chapters, the following conclusions can be drawn as offering solutions to the problems identified in this study. First, the taxpayers involved in transfer pricing disputes related to intragroup services tend to have been exposed to many prior tax disputes that have been brought to the Tax Court. Most of the corrections made by the DGT on intra-group services transactions were related to the corrections on other types of tax. An intra-group services transaction tended to be scrutinized if it was a cross-border transaction.

Second, with regard to the taxpayer's relationship with the service providers, the DGT mostly made a correction on intra-group services provided by the (direct/indirect) shareholders of the taxpayers. Further, the DGT's corrections tended not to consider whether there are tax motives.

Third, the recent trend of transfer pricing disputes related to the correction of intra-group services transactions in Indonesia is that the DGT's assessment is mostly based on the conclusion that the taxpayer had/maintained a lack of supporting evidences to prove the existence issue, benefit issue, and the arm's-length charges. This study also found that none of the above cases were disputed on the determination of the analysis of the service providers' 
arm's-length returns.

Fourth, during the tax appeal process, more than half of the Tax Court's decisions were in favor of the taxpayer (in other words, cancelled the DGT's correction) and the rest of were in favor of the DGT (or upheld the DGT's correction). Almost half of the considerations of the judges of the Tax Court in cancelling the DGT's correction were because the supporting evidences provided by the taxpayer during the tax audit process were already considered sufficient. Only $22.73 \%$ of the Tax Court's decisions still considered only the supporting evidences submitted after the tax audit process and concluded that these supporting evidences should be considered sufficient. This result was triggered by the fact that there are different interpretations of the criteria of evidences by the DGT and the Tax Court, leading to different views on the supporting evidences during the tax audit and tax objection process and the tax appeal process.

Fifth, during the judicial review process, $80 \%$ of the Supreme Court's decisions upheld the Tax Court's decision, and the remaining $20 \%$ cancelled the Tax Court's decision. This is influenced by the fact that during the judicial review process, most of the cases required the judges merely to assess whether the Tax Court's decision was already in compliance with the prevailing laws and regulations.

Sixth, the latest development of international transfer pricing guidelines (specifically as issued by OECD) related to intra-group services is mainly an introduction to a simplified approach for compliance to the arm's-length principle of low value-adding services. The simplified approach may seem to be beneficial to the taxpayer utilizing the low value-adding intra-group services scheme, as it details specific guidelines on a simpler approach for the provision of low value-adding intra-group services whereby the qualification of the supporting evidences and even the arm's-length charges are already determined in this guideline. The taxpayer's compliance effort to satisfy the benefits test and to demonstrate the arm's-length charges will be minimized given that the taxpayer need only maintain the payroll processing and a single annual invoice describing a specific service category, and it also provides greater certainty for multinational enterprise groups on the tax authority's acceptance to their intra-group services arrangement.

Seventh, however, given that Indonesia has a specific economic condition which is below the economic condition of more developed countries where the related party service provider (e.g., headquarters or parent of the taxpayer's group of companies or the designated group member) operates, duly considering the options realistically available, the intra-group services provided by overseas related parties are inclined to be seen as having been arranged with transfer pricing motives. Accordingly, the view on the existence of similar services to be obtained in Indonesia with lower prices becomes arguable and may reasonably be subject to the supporting evidences provided.

The limitation of this study is that it relied on the publicly available data based on internet reviews on reliable websites. No interviews were conducted with the taxpayers discussed in this study, and no data were retrieved directly from the taxpayers. This study relied on the Supreme Court's databases of decisions which were uploaded to its official websites.

\section{REFERENCES}

[1] Deloitte. The new transfer pricing landscape: a practical guide to the BEPS changes, Deloitte (2015).

[2] PMJL Hutagaol. Updates in Indonesian taxation. Paper presented at DGT’s Presentation in Tokyo, Japan (2016).

[3] Organisation for Economic Co-operation and Development (OECD). OECD transfer pricing guidelines for multinational enterprises and tax administrations 2017, OECD Publishing, Paris (2017).

[4] Ernst \& Young (EY). Unraveling tax issues in the value chain, EY Global Tax Weekly 16 April 2015, London (2015).

[5] EYGM Limited. Worldwide transfer pricing reference guide 2015-16, EYGM Limited (2016).

[6] G. Richardson, G. Taylor, and R. Lanis. Determinants of transfer pricing aggressiveness: empirical evidence from australian firms, Journal of Contemporary Accounting \& Economics, 9(2) (2013) 136-150.

[7] L. K. Siahaan and R. Riandako. Analisis kewajaran transaksi jasa intra-grup, Jurnal Informasi Keuangan dan Akuntansi, 2(12) (2014).

[8] Deloitte. The New Transfer Pricing Landscape, A Practical Guide To The BEPS Changes. November 2015. 